\title{
Rationale of Pancheshwar Multipurpose Project for Reduction of Energy Crisis and Mitigating the Impacts of Mahakali Flood and Subsequent Economic Development of Nepal and India
}

\author{
Moti Bahadur Kunwar
}

\begin{abstract}
The proposed 315m high dam Pancheshwar Multipurpose Project (PMP) is a bi-national scheme on the Mahakali River that forms the border between Nepal and India. In the first week of July 2013, flooding on the Mahakali River caused extensive damages in district headquarter of Darchula district of Nepal and downstream area. The implementation of the proposed Pancheshwar Multipurpose Project $(6480+240 \mathrm{MW})$ could solve the current energy crisis, provide flood control, and generate reliable source of revenue from the export of hydropower for both Nepal and India. However, despite the possible advantages, PMP is still only a plan 18 years after its initiation with the 1996 Mahakali Treaty ratified by the Nepalese parliament. Therefothere, Pancheshwar Multipurpose Project should be jointly developed as soon as possible for the mutual benefit of both nations.
\end{abstract}

Key words: Hydropower, Mahakali River, Pancheshwar project, Nepal, India

\section{Introduction}

Tepal has a large, untapped potential for hydropower 1 development, one of the few major development options currently available to the country. The theoretical hydropower potential of Nepal is estimated to be 83,000 MW of which 43,00oMW is commercially viable. The present installed capacity of the Integrated Nepal Power System (INPS) is 765 MW. The energy and peak power demand of INPS in 2013 grew by $7.7 \%$ and 9\% over the previous two years, respectively (NEA-2012/13). Many professionals believe this is suppressed demand due to non-availability of sufficient power. In wet season, there is capacity deficit of $16 \%$ compared to a $58 \%$ deficit in dry season that results in load shedding of 12-18 hours per day (Kunwar 2012). Currently, 67.26\% of the population has access to electricity (Nepal 2012 Census Report). Annual peak power demand by 2013 is estimated approximately 1,200 MW (Baral 2013). The annual per capita electricity consumption in Nepal is below 100 units per annum.

Meanwhile, during 2006-07, India faced a peak power deficit of $13.5 \%$ and power supply deficit of $9.9 \%$. India's northern region had corresponding peak power deficit of $11.3 \%$ and power supply deficit of 10.9\% (Central Electricity Authority 2007). Currently, Bihar, Uttar Pradesh, Uttarakhand and New Delhi region of India are facing a collective power deficit of approximately 10,000 MW (Shrestha 2013). These deficits are set to increase despite a significant India's effort to improve its installed capacity over the last decade. These efforts, it should be noted, harness electrification from coal, hydropower, nuclear power and solar to overcome the deficit, all of which have more serious environmental impacts than hydropower. Thus, these shortages in India make hydropower development in the Himalayan region, especially Nepal and India an economically viable alternative to additional thermal power development.

\section{Pancheshwar Multipurpose Project (PMP)}

Pancheshwar Multipurpose Project (PMP) has been conceived as a bi-national project to be developed on the Mahakali River that forms the international border between Nepal and India. The proposed Pancheshwar High Dam on Mahakali River is located $2.5 \mathrm{~km}$ downstream from the confluence of Mahakali and Saryu rivers flowing from India at Pancheshwar in adjoining Baitadi district of Nepal. Different study reports of the project revealed that the construction of 315m Pancheshwar High dam will create a $65 \mathrm{~km}$ long reservoir from Rolghat of Pancheshwar VDC in Baitadi district to Dattu of Dattu VDC in Darchula district. The reservoir will hold 6.56 billion cubic meters of water $\left(\mathrm{m}^{3}\right)$ and be capable of generating 10,671 gigawatt-hours (GWh) of energy with an installed capacity of 6,480 MW (Detailed Project Report, 1995). Two identical underground powerhouses, one on each bank in Nepal

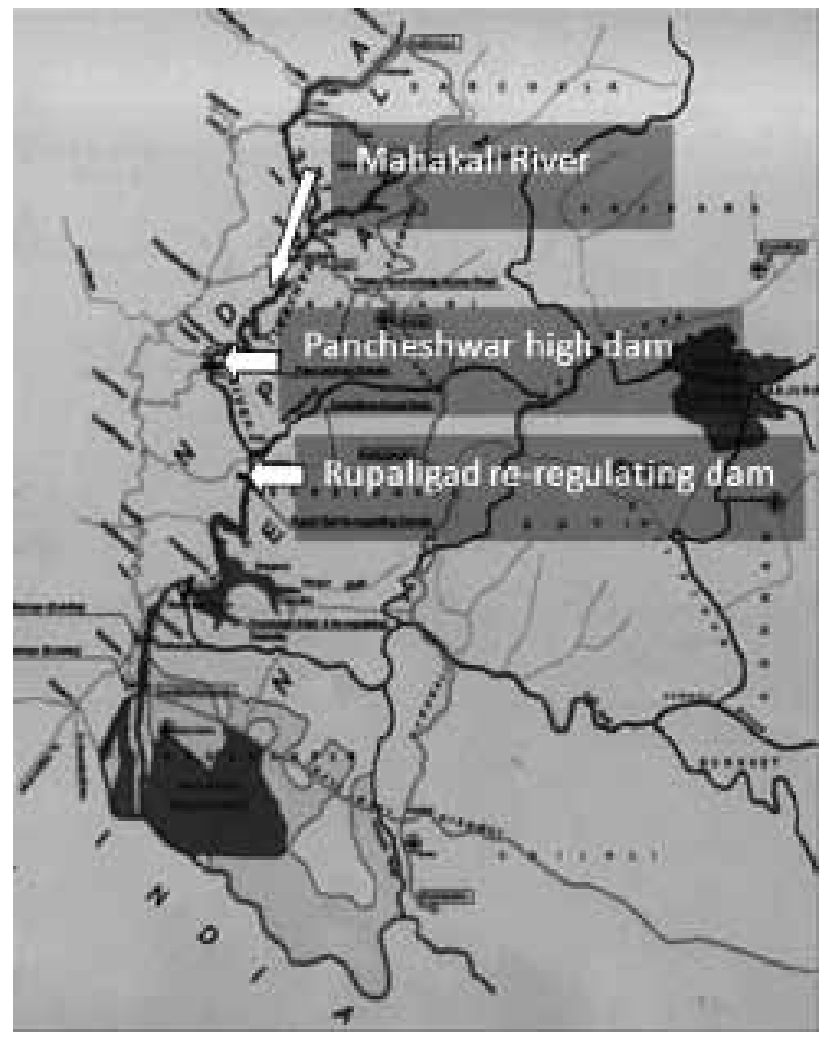

Figure 1. Location Plan of the Dam Site 


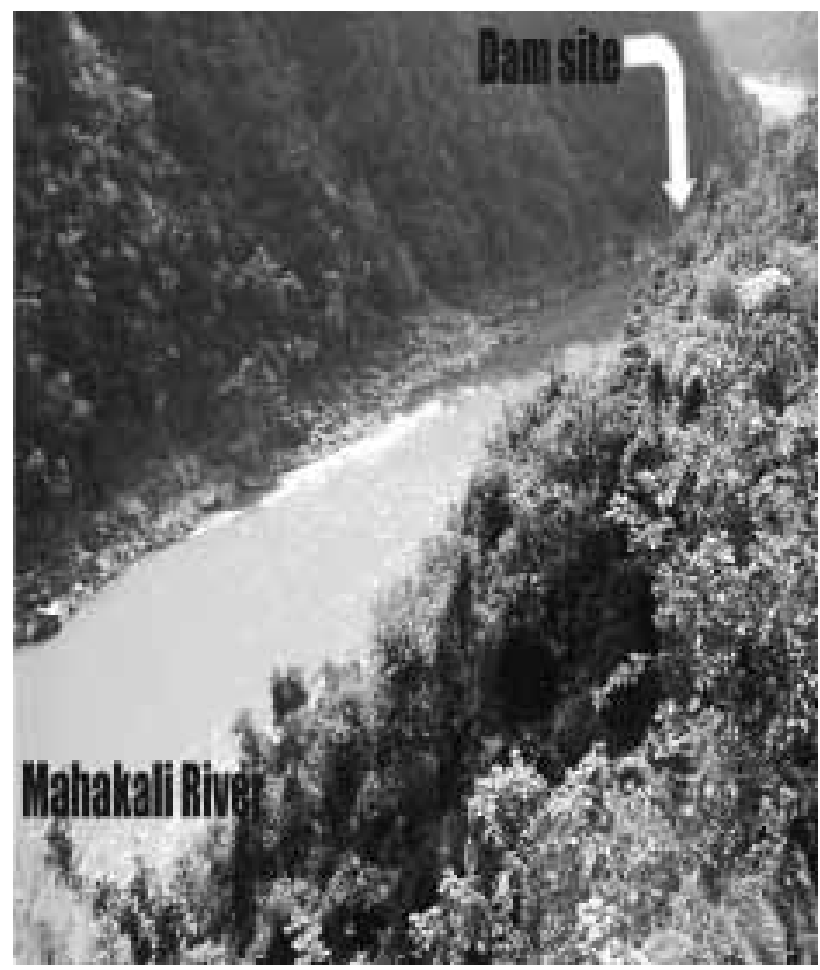

Figure 1.1. The Dam Site

and India have been proposed. The project has proposed a 83m high concrete dam at Rupali Gad (re-regulating dam) which is approximately $25 \mathrm{~km}$ downstream from the Pancheshwar High Dam. The dam will create a live storage of 70 million $\mathrm{m}^{3}$ of water and be capable of producing average annual energy of $1,650 \mathrm{GWh}$. The installed capacity of the powerhouse will be $240 \mathrm{MW}$ of which $120 \mathrm{MW}$ will be installed in Nepalese side.

\section{Important Clauses of Mahakali Treaty for PMP Implementation}

The Mahakali Treaty (1996) contains several clauses related to developing PMP. They are noted here.

\section{Article 3, Paragraph 1 of Mahakali Treaty}

"Pancheshwar Multipurpose Project (hereinafter referred to as the "Project") is to be constructed on a stretch of the Mahakali River where it forms the boundary between the two countries and hence both the Parties agree that they have equal entitlement in the utilization of the waters of the Mahakali River without prejudice to their respective existing consumptive uses of waters of the Mahakali River."

\section{Article 3, Clause 2 of Mahakali Treaty}

"The Project shall, as would be agreed between the Parties, be designed to produce the maximum total net benefit. All benefits accruing to both the Parties with the development of the Project in the forms of power, irrigation, flood control etc. shall be assessed"

\section{Article 3, Clause 3 of Mahakali Treaty}

"The cost of the Project shall be borne by the Parties in proportion to the benefits accruing to them. Both the Parties shall jointly endeavor to mobilize the finance required for the implementation of the Project"

\section{Article 3, Clause 4 of Mahakali Treaty}

"A portion of Nepal's share of energy shall be sold to India. The quantum of such energy and its price shall be mutually agreed upon the parties'.

\section{Item 3(a) of the Letters of Exchange}

"While assessing the benefits from the project during the preparation of the DPR, net power benefits shall be assessed on the basis of, interalia, saving in costs to the beneficiaries as compared with the relevant alternatives available".

Regarding electricity export to India, Pun (2010) has stressed that Nepal should share India's point of view on the basis for sale price of Nepal's portion of electricity to be exported from Pancheshwar Project.

\section{Lessons Learned from Tehri Dam, India}

The Tehri Dam Project located in the Bhagirathi River in Garhwal District of Uttarakhand is a $261 \mathrm{~m}$ high rockfilled dam with an installed capacity of $1000 \mathrm{MW}$ (first phase) and 2.615 billion cubic meters of storage reservoir. The Tehri Dam Project consists of three stages. The project was started in 1978, the first (1000 MW) and second phases (400 MW) were completed in 2006 and 2012 respectively. The third stage will lift the water from the lower Koteshwar Dam to upper Tehri Dam and will generate 1,00o MW of power during peak hours (a pumped storage system). During the course of implementation, this project faced several social, legal and engineering challenges. Local activist and environmentalists filed court cases against the project. Despite those challenges and issues of environment, potential seismic hazards, and rehabilitation and resettlement, the Government of India has boldly shown its commitment towards the execution of high dam project in Himalayan region (Adhikari 2009).

The share equity investment on the hydropower is $75 / 25$ for the central and state governments, respectively, while the irrigation component is solely financed by the state government of Uttar Pradesh. The Tehri Dam will irrigate 0.874 million hectares in Uttar Pradesh and provide drinking water to Uttar Pradesh and Delhi as well as power generation. Implementation of pumped storage projects mentioned above gives the importance of the peaking value of electricity generated from a storage project.

\section{Mahakali Floods}

Originating from the high Himalayan region, the Mahakali River flows along Darchula, Baitadi, Dadeldhura and Kanchanpur districts of Nepal as a border between Nepal and India. Although, the catchment area spreads across both Nepal and India, the study (DPR, 1995) reveals that the catchment area in the Indian territory is two-thirds of the total catchment. The main tributaries of Mahakali River are Dhauli Ganga, Gori Ganga, Ram Ganga and Saryu in India and Chamelia River and Parmoli Gad within Nepal. India has already constructed a 280 MW Hydroelectric Project in Dhauli 
Ganga upstream of proposed dam site of Pancheshwar while Nepal is also constructing a $30 \mathrm{MW}$ project called Chamelia. The floods in the Mahakali River affect all four (Darchula, Baitadi, Dadeldhura and Kanchanpur) districts of the Mahakali Zone on both sides of the river. The flooding washes away hundreds of hectares of agricultural land, human settlement, forest area, and other infrastructures. In previous years, the maximum discharge of Mahakali River was 400,000 cusecs while in 2013, it reached 461,000 cusecs (Rajdhani daily (Kathmandu), 2070/03/o5 (June 19, 2013), inducing a devastating flood downstream of the Pancheshwar High dam. The 2013 flood washed away 122 houses, 4 temples, 13 government offices, and destroyed 105 houses while displacing more than 2,500 individuals in the district headquarters of Darchula district during the first week of Ashad (Kantipur daily (Kathmandu), 2070/o3/21 (July 5 , 2013). The huge damages were in Darchula, upstream of Pancheshwar.

Water from the upper catchment can be stored during monsoon season to safeguard the upstream and downstream region from devastating floods. The downstream region below Rupali Gad includes Rupal, Jogbudha and Sirsa VDCs of Dadeldhura district and certain wards of the Bhimdutta Municipality including Dodhara and Chandani VDCs of Kanchanpur District. Only after the construction of the Pancheshwar High Dam and Rupali Gad re-regulating dam, flooding in the upstream and downstream region can be controlled. Estimated design flood for Pancheshwar is $23,500 \mathrm{~m}^{3} / \mathrm{s}$ $(8,22,500$ cusecs) (DPR, 1995).

Adopting various mitigation measures and enhancement plans in immediate catchment areas (65 $\mathrm{km}$ upstream and $25 \mathrm{~km}$ downstream) of Pancheshwar High Dam will reduce flood impacts. In this scenario, Pancheshwar Multipurpose Project in Nepal is planning to develop a Detailed Catchment Area Development Plan (DCADP) for environmental management and catchment area development of the region. The Environmental Impact Assessment (EIA) of Pancheshwar Dam and Detailed Environment Management Plan (DEMP) on the Nepalese side are in the final stages of study.

The devastating floods in the Kedarnath temple region in India cost several thousand human lives in the last monsoon and might have been prevented to a large extent with a flood dedicated storage project that could limit such a catastrophe. Furthermore, flooding on the Mahakali requires that the Indian and Nepalese governments pay out significant sums of money in compensation each year.

\section{Impacts of Pancheshwar Multipurpose Project}

PMP will produce various positive and negative impacts which are mentioned below:

\section{Beneficial Impacts}

Successful implementation of Pancheshwar Multi purpose Project will minimize energy shortages, control of flood disaster, promote irrigation facilities and increase agricultural productivity, and help develop tourism and other commercial activities in the Nepal and India. The Detailed Feasibility Study Report shows that this project is one of the cheapest hydropower projects in the world in terms of cost against unit of energy produced (DPR, 1995; Total cost: 2,980 million US\$, EIRR: 25.4\%, BC Ratio: 2.52, Energy Production Cost: $3.4 \mathrm{c} \$ / \mathrm{kWh}$ and Unit Cost of Installed Capacity: 445 US $\$ / \mathrm{kW}$ ). It has been estimated that Nepal will generate approx. NRs.53.41 billion per annum of revenue from this project (Electricity: Rs. 34.50 billion/year, Fisheries: Rs. 9.08 billion/year, Irrigation: Rs. 5.55 billion/year, Carbon trading: Rs. 4.42 billion/year, Agricultural production loss: Rs. 138.58 million/year) (EIA, 2009). Similarly, India will generate more revenue from this project than Nepal.

\section{Benefits to the State of Uttarakhand and UP}

From PMP, India will receive irrigation benefits in 1.6 million ha of farmland compared to 93,00o ha for Nepal. India's economy will be significantly boost up from this project. It is a normal practice to receive about $12-13 \%$ free energy to the State from the proposed hydro projects. In addition, there will be substantial benefits due to flood control and benefits from regulated water. During construction period, there will be job opportunities for thousands of people in the area.

\section{Clean Development Mechanism (CDM)}

Emission of carbon dioxide $\left(\mathrm{CO}_{2}\right)$ from the use of fossil fuels has resulted in global warming on a large scale that, in turn, has induced climate change. In

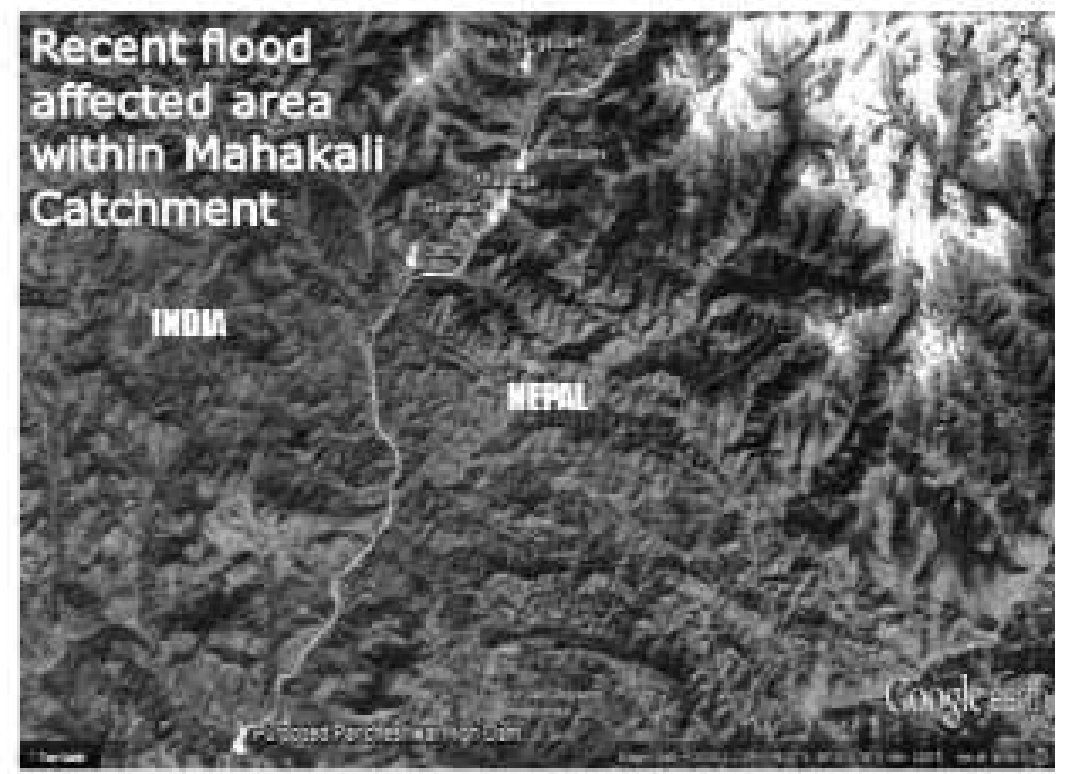

Figure 2. Flood Affected area within the Mahakali Catchment 
order to mitigate this problem, the Clean Development Mechanism (CDM) has been put in place, a mechanism within the Kyoto Protocol that allows industrialized countries to implement projects that reduce emissions in developing countries and receive credits for meeting their commitments to reduce emissions. Generation of hydropower results in environmental additionality due to its carbon offset for not emitting greenhouse gases (GHG) in the environment. The price of carbon offsets (also known as carbon credits) range from $\$ 5$ to $\$ 15$ per ton of $\mathrm{CO}_{2}$ equivalent (Shrestha 2009). It is envisaged that Nepal would be earning approximately Rs. 4.42 billion per annum half of the total in carbon credits (Singh 2011). The Pancheshwar agreement had not envisioned CDM aspect. It needs to be revised so that both the countries equally share this benefit.

\section{Unmet Water Demands in India}

The unmet water demands for 2007-2008 cropping patterns in the Upper Ganga Basin (India) was $160,185,215$ and 205 million cubic meters (MCM) for the month of Nov, Dec, Jan and February months (Sapkota et al., 2012). Storage reservoirs will play a crucial role in minimizing the unmet water demand in domestic, industrial and agricultural water use. Further, reservoir project will provide cushion for the erratic monsoon due to climate change.

\section{Probable Cost Sharing}

In the $5^{\text {th }}$ meeting of Nepal-India Joint Committee on the Water Resources (JCWR) on November 2009, it was informally agreed that the project will result in $75 \%$ hydropower and $25 \%$ irrigation/flood control benefits. The $25 \%$ irrigation benefits to India were figured after rigorous exercises by the experts of both teams. The hydropower benefits will be shared equally whereas large portion of irrigation and flood control benefits goes to India resulting in an overall cost sharing of $62.5 \%$ India and $37.5 \%$ Nepal.

\section{Adverse Impacts}

The major negative impacts identified in Nepal are involuntary displacement of approximately 22,765 persons from 2,926 households, submergence of approx. 6000 ha of land, agricultural production loss of Rs. 138.58 million per annum, disturbance in law and order situation, pressure on forest, public utilities and other natural resources, pollution, micro-climatic change, change in land use, impacts on riverine ecology and aquatic life/habitat etc. However, all these negative impacts can be mitigated to acceptable level during project development stage.

\section{Climate Change}

Due to climate change, monsoon season has become erratic and in the long run, river discharge is expected to be reduced. A study undertaken in Bhutan by the Norwegian Water Resources Directorate has revealed that the Wangdirapids flow will be highly reduced onwards starting in 2051 and by 2075, the average flow will be half (Beldring et al., 2009). A similar situation can be visualized for the Mahakali River which justifies the importance of storage project.

\section{Socio-economic Impacts of Project Delay}

Due to energy crisis, Nepal is losing approximately NRs.55 billion per year (Kunwar 2012). Consequently, Nepalese economy has been crippled in regard to industrial production, commercial activities, tourism industry and other services like communication, education, health, irrigation, drinking water, transportation as well as increase in unemployment, which may derail the peace process and transition phase. Electricity generated from NEA owned hydropower projects, the operation of costly diesel plants, the purchase of all excess energy from IPPs and all possible import under power exchange agreement and power trade with India might ameliorate the crisis. However, these measures are insufficient to fulfill the huge gap between demand and supply. Similar situation has also been observed in India due to project delay. With the adequate supply of power, the demand for industrial and commercial use is expected to grow rapidly. Rapid growth of industrial establishments requires more reliable and sufficient supply of power in future. Therefore, it is very urgent to implement PMP as early as possible to promote socio-economic conditions of Nepal and India by reducing energy crisis in the region.

\section{Present Status of PMP}

The Mahakali Treaty clearly states that the water and electricity shall be shared in the ratio of 50:50 by both the countries. A portion of Nepal's share of energy shall be sold to India at a price to be mutually agreed upon by the parties. Even after 18 years of treaty between Nepal and India, the proposed Pancheshwar Project to be built for mutual benefits under the treaty has not been finalized (even though it was proposed initially that the final DPR be prepared within six months after treaty). Similarly, the Pancheshwar Development Authority (PDA) which was to be formed between the parties under the treaty could not be constituted, which is the major factor for delaying the implementation of Pancheshwar Multipurpose Project. Consequently, both countries are still facing flood disaster and several hours of load shedding per day. The Government of Nepal (GoN) has already approved the Terms of Reference (ToR) for the PMP's PDA while it is still under consideration from Indian side.

\section{Conclusions}

As PMP has several benefits of power, irrigation and flood control, fulfill the unmet water demands by regulated flows, cushion against the climate change, very high socio-economic benefits, possibility of high value peaking electricity, CDM benefits etc., the implementation of 
PMP should not be delayed.

People of this Basin (Nepal/India) are being deprived of the benefits of PMP. They have a right to question "Why there is so much delay in starting the PMP?" Therefore, this is high time to implement one of the most promising multipurpose projects as a backbone for the economic development and prosperity of Nepal and India with positive initiation from all stakeholders: political parties, local people of Far-Western region, people of Uttarakhand/Uttar Pradesh, India, civil society, the Government of Nepal, and the Government of India. The project cost sharing mechanism should be finalized with great faith and confidence between Nepal and India to ensure mutual benefits for both countries.

Moti Bahadur Kunwar, Master of Hydrology and Water Resources from University of Roorkee, India, (1986) and Master of Engineering Geology from Tribhuwan University, Nepal (1980) is the project manager of Pancheshwar Multipurpose Project and joint secretary at the Ministry of Energy, Government of Nepal. He writes regularly on energy and water issues.

Corresponding address: motikunwar@hotmail.com

\section{References}

Adhikari, B. R., July 2009. Tehri Dam: An Engineering Marvel, Hydro Nepal Journal, Issue No. 5, pp. 26-30.

Baral, S., 2013. Present Status of Hydropower Development in Nepal. Fundamentals of Hydropower Engineering. Second Revised Edition. Engineering and Educational Services Pvt. Ltd., Kathmandu.

Beldring, S., and Voksø, Astrid, July 2012. Climate Change Impact on Flow Regimes of Rivers in Bhutan and Possible Consequences for Hydropower Development, Hydro Nepal Journal Issue No. 11, pp. 67. Summary of the Report published in Hydro Nepal
Journal.

Central Electricity Authority. URL: http://www.cea.nic. in/

Kantipur Daily (Kathmandu), July 5, 2013.

Kunwar M.B., 2012, Water Resources and Hydropower Development Scenario of Nepal and its Potentiality in Kaligandaki Basin and Parbat District, Western Nepal. Parbat Bikas Punja.

Nepal 2012 Census Report: All Info about Nepal. URL: http://www.cbs.gov.np/

NEA (Nepal Electricity Authority), (2012/2013), A Year in Review- Fiscal Year 2012/2013, August 2013, Kathmandu, MD’s Report, 120 pp. URL: http://www. nea.org.np/

Nepal Electricity Authority. URL: http://www.nea.org.np/

PACO (Pancheshwar Consortium), 1995, Pancheshwar Multipurpose Project, Detailed Project Report, Vol. 1, 2 and 3, Nepal.

Pun, SB., January 2010. Pancheshwar Multipurpose Project: Nepal's Portion of Power, Hydro Nepal Journal, Issue No. 6, pp. 2-6.

Rajdhani Daily (Kathmandu), June 19, 2013.

Sapkota, Pratibha; Bharati, Luna; Gurung, Pabitra; Kaushal, Nitin; and Smakhtin, Vladimir, July 2013. Environmentally sustainable management of water demands under changing climate conditions in the Upper Ganges Basin, India. Hydrological Processes, Special Issue: The Hydrology of Large Rivers, Vol, 27, Issue 15, pp. 2197-2208.

Singh, DB., 2011. Thinking Big: For the Sustainable Development of Multipurpose Projects. Unpublished Report.

Shrestha, AK., 2013. Status and future of Nepal's Hydropower Development. Dolakha Bikaas Manch.

Shrestha, RS., July 2009. West Seti Hydroelectric Project: Assessment of its Contribution to Nepal's Economic Development, Hydro Nepal Journal, Issue No. 5, pp. 8-17.

\section{CALENDAR OF EVENTS - IRRIGATION}

28-29 April, 2014, National Irrigation Seminar on Irrigation to all Cultivable land: Challenges and Opportunities, Location- Kathmandu, Nepal; Contact: Er. Basudev Lohanee, Ph no: 9841 277760, email:lohanibasu@yahoo.com and Er. Basudev Timilsina, Ph no: 9841516405, email: basutimilsina@yahoo.com

23-26 June 2014 12th International Drainage
Workshop (IDW), 23-26 June 2014, St. Petersburg, Russia. Location : Moscow, Russia.Website: http:// onlinereg.ru/IDW12, E-mail : ibond@online. ru, rusiptrid@mail.ru

14-20 Sept. 2014, 22nd ICID Congress and 65th Meeting, Location : Gwangju, Korea, Contact: 22nd ICID Congress Secretariat: E Mail: icid2014@icid2014.org 